\section{References}

APPLEBY, L., SHAW, J., KAPUR, N., et a (2006) Five Year Report of the Nationa

opinion

\& debate

Confidential Inquiry into Suicide and
Homicide by People with Mental Illness. University of Manchester.

BARHAM, P. (1992) Closing the Asylum - The Mental Patient in Modern Society. Penguin Books.

BIRMINGHAM, L. (1999) Between prison and the community. The 'revolving door psychiatric patient' of the nineties. British Journal of Psychiatry, 174, 378-379.

BMJ (1895) Lunatics at large. BMJ, 1, 799-800.

COID, J., KAHTAN, N., GAULT, S., et al (2001) Medium secure forensic psychiatry services. Comparison of seven English health regions. British Journal of Psychiatry, 178 $55-61$

COID, J.W., HICKEY, N. \& YANG, M. (2007) A comparison of outcomes following after-care from forensic and general adult psychiatric services. British Journal of Psychiatry, 190, 509 514.

DEPARTMENT OF HEALTH (1998) Modernising Mental Health Services: Safe, Sound and Supportive (HSC 1998/ 233: LAC(98)35). Department of Health.
DOWSETT, J. (2005) Measurement of risk by a community forensic mental health team. Psychiatric Bulletin, 29, 9-

DUGGAN, C. (1997) Introduction. British Journal of Psychiatry, 170 (suppl. 32), 1-3.

DYER, O. (2003) Conditions at Broadmoor come under attack from inspectors. BMJ, 327, 1250 .

GOFFMAN, E. (1961) Asylums: Essays on the Social Situation of Menta Patients and Other Inmates. Doubleday.

GOLDBERG, D. (2006) The state of British psychiatry. Progress in Neurology and Psychiatry, 10, 12-16.

\section{HOME OFFICE \& DEPARTMENT OF} HEALTH AND SOCIAL SECURITY (1975)

Report of the Committee on Mentally Abnormal Offenders (The Butler Report), Cmnd 6344. HMSO.

INFORMATION CENTRE (2006) Inpatients Formally Detained in Hospitals under the Mental Health Act 1983 and Other Legislation, England: $1994-5$ to 2004 -5 (Bulletin: 2006/09/HSCIC). Information Centre, UK Government Statistical Centre.

JONES, K. (1993) Asylums and After. A Revised History of the Mental Health Services. Athlone Press.
KILLASPY, H., BEBBINGTON, P., BLIZARD, R., et al (2006) The REACT study: randomised evaluation of assertive community treatment in North London. BMJ, 332, 815-820.

LINK, B. ANDREWS, H. \& CULLEN, F.T. (1991) The violent and illegal behaviour of mental patients reconsidered. American Sociological Review, $5 \mathbf{7}$ 275-292.

MADEN, A. (2005) Violence risk assessment: the question is not whether but how. Psychiatric Bulletin 29, 121-122.

MONAHAN, J., STEADMAN, H., SILVER, E., et al (2001) Rethinking Risk Assessment. The MacArthur Study of Mental Disorder and Violence. Oxford University Press.

MOON, G. (2000) Risk and protection: the discourse of confinement in contemporary mental health policy. Health and Place, 6, 239-250.

MULLEN, P. (2006) Schizophrenia and violence: from correlations to preventive strategies. Advances in PsychiatricTreatment, 12, 239-248.

*TrevorTurner Consultant Psychiatrist, City and Hackney Centre for Menta Health, Homerton University Hospital, London E9 6SR, email: trevor.turner@ elcmht.nhs.uk, Mark Salter Consultant Psychiatrist, City and Hackney Centre for Mental Health, Homerton University Hospital, London
PHILO, G., SECKER, J., PLATT, S., et al 1994) The impact of the mass media on public images of mental illness: media content and audience belief, Health Education Journal, 53, 271-281.

PRIEBE, S. \& TURNER, T. (2003) Reinstitutionalisation in mental health care. BMJ, 326, 175-176.

SCOTT, P. (1977) Assessing dangerousness in criminals. British Journal of Psychiatry, 131, 127-142.

SZMUKLER, G. (2001) Violence risk Psychiatry, 178, 84-85.

TUDDENHAM, L. \& HUNTER, R. (2005)

Prosecution of violent patients. Psychiatric Bulletin, 29, 275 .

TURNER, T. \& SALTER, M. (2005) What is the role of a community forensic mental

WARD, G. (1997) Making Headlines. Health Education Authority.

WILKINSON, J. (2003) The politics of risk and trust in mental health. Critical Quarterly, 46, 82-102. prediction in practice. British Journal of healthteam? PsychiatricBulletin, 29,352.

\title{
JOHN O'GRADY
}

\section{Time to talk. Commentary on... Forensic psychiatry and general psychiatry ${ }^{\dagger}$}

It is indeed time for general and forensic psychiatrists to work together to improve services for mentally disordered offenders and others with similar problems. To achieve this, we must understand one another. Turner \& Salter (2008, this issue) are unhappy with the definition of forensic psychiatry as 'patients and problems at the interface of law and psychiatry'. I consider this to be an accurate, pithy and practical definition. It establishes forensic psychiatry as the branch of psychiatry that deals specifically with mentally disordered offenders (patients at the interface of law and psychiatry) and that works alongside criminal justice agencies, including courts and prisons, to meet their needs. The authors are quite wrong in equating the development of forensic psychiatry with society's preoccupation with risk. Forensic psychiatric services were developed in the context of a liberal public policy tradition that seeks to divert mentally disordered offenders from criminal justice to health and social care.

†See pp. 2-6, this issue. produced the widely quoted circular 66/90, which stated that public policy in regard to mentally disordered offenders is that they should receive their care and treatment within the National Health Service (NHS) rather than the penal system. This long-standing liberal tradition in English Law is reflected in Section 37 of the Mental Health Act 1983 (originating in the 1959 Act), which allows for offenders who have been found guilty of even the most serious violent offences to be dealt with by means of a disposal to healthcare rather than punishment in prison. This sets forensic psychiatric provision in the UK apart from other jurisdictions without such an enlightened and liberal attitude towards offender patients. The authors may, as citizens, object to the allocation of significant resources to the management of offenders, but as psychiatrists they should celebrate the commitment by society of resources to provide treatment for offenders with mental disorder in health settings rather than in a penal institution.

The authors seem to fall into the trap of minimising the correlation between violence, offending, substance 
misuse, antisocial personality and major mental illness. Thus, they talk about mental illness being only a moderate risk factor for the occurrence of violence and put emphasis on non-psychiatric variables being associated with violence and offending. The inference seems to be that there should be a clear division between managing the mental disorder within health systems and the offending within criminal justice systems. If we take on, as we should, the treatment of mentally disordered offenders then that treatment must address not only health but offending and antisocial behaviours. The authors then describe the actual workload of general psychiatrists, this comprising 'poorly compliant, treatment-resistant patients... who have constant offending histories and poor impulse control' and who 'come in and out of general acute wards...', suggesting that our patient groups have much in common, which should lead to development of common treatment approaches and facilities. There is sufficient known about the relationship between serious mental illness, offending, substance misuse, and childhood-onset antisocial behaviour patterns to recognise that psychiatry has to develop services designed to meet their particular needs. That violence and mental disorder, particularly schizophrenia, are strongly linked is, as the authors point out, no longer a controversial finding. There should be a common agenda for forensic, general and rehabilitation psychiatry regarding the needs of patients with complex problems who cannot be managed safely without structure, service design based on their actual needs, and appropriate use of security, coercion and mental health legislation, including community treatment orders. This not only requires a radical expansion of low secure provision but also the development of pathways of care that emphasise the need for long-term rehabilitation, adequate community provision of specialist housing in areas not blighted by drugs and high crime rates, specialist employment schemes and an adequate legal framework to ensure consistent, safe and effective treatment.

As long as the response from psychiatry to mentally disordered offenders is to 'redistribute the resources... to provide care for the majority rather than a minority of patients' and for 'management of people with mental illness who offend [to] be relocated to improved healthcare sections of the prison environment', forensic psychiatry and general psychiatry will be in conflict. The hard fight over two centuries to gain resources for mentally disordered offenders will not be abandoned easily. The direction of travel must be towards greater availability of treatment facilities right across the spectrum of diagnosis and need, with greater integration between general and forensic services. Psychiatrists should be supportive of those pioneering forensic psychiatrists who are trying to develop treatment systems for patients with severe personality disorder whether that is in hospital or prison settings. We should, as concerned clinicians, be arguing not for a reversal of humane welfare provision for mentally disordered offenders but for ever greater involvement of health within criminal justice so that the disadvantaged, disordered and socially excluded within society can be provided with adequate resources to meet their welfare needs and tackle their offending.

Forensic psychiatrists have never viewed risk assessment as being their exclusive prerogative. In fact, the Faculty of Forensic Psychiatry has long argued that the College should recognise the clear link between mental illness, offending and violence and embrace the sound evidence base that now exists for structured clinical risk assessment and management. The training curricula for the various psychiatric specialties reflect this view.

There are strong arguments for our separate specialties merging at some time in the future. That point has not yet been reached and, therefore, for the immediate future we must remain separate. An examination of the curricula for training in general or forensic psychiatry would be a good starting point for understanding areas where we have common ground but would also point to significant differences between the training and orientation of our different services. I suspect that Turner \& Salter are describing a problem peculiar to London, as elsewhere there appears to be better integration between general and forensic services. The excellent working relationship between forensic and general psychiatrists in some prison in-reach services shows that integration is possible to our mutual benefit. Dialogue, mutual respect and understanding are likely to lead to fruitful interchange in the future.

\section{References}

TURNER, T. \& SALTER, M. (2008) Forensic psychiatry and general psychiatry: re-examining the relationship. Psychiatric Bulletin, 32, $2-6$
John O'Grady Consultant Forensic Psychiatrist, Ravenswood House MSU, Fareham, Hampshire P017 5NA, email: john.o'grady@hantspt-SW.nhs.uk, and Chair, Faculty of Forensic Psychiatry, Royal College of Psychiatrists, London 